\title{
Decolonizing hybridity: indigenous video, knowledge, and diffraction
}

\author{
cultural geographies \\ 19(3) 329-348 \\ (C) The Author(s) 2012 \\ Reprints and permission: sagepub. \\ co.uk/journalsPermissions.nav \\ DOI: | 0. I I77/|4744740 I |429407 \\ cgj.sagepub.com \\ (S)SAGE
}

\section{Laurel C Smith}

University of Oklahoma, USA

\begin{abstract}
This article examines the hybrid cultural geographies of indigenous video with Donna Haraway's visual strategy of diffraction. Drawing on ethnographic inquiry, one particular video is explored from three different perspectives. First, a festival audience celebrates how the video represents place-based belonging, the joys of collective labor, and indigeneity. Second, a geographical analysis articulates the transnational circuits of advocacy and collaborative practices of knowledge production that shaped this video and its subsequent travels. Third, an extended conversation with the video maker about his target audience reveals a political intervention not visible from the first two angles of analysis. When diffracted, this thrice-told story about one video provides lessons about the potential for indigenous video to decolonize scholarly authority.
\end{abstract}

\section{Keywords}

audience, cultural activism, indigenous video, Oaxaca Mexico, transnational advocacy

\section{Introduction}

Comunicadores indigenas ${ }^{1}$ use video technologies to tell experience-based and communitycentered stories. Their videos often respond to the structural and symbolic marginalization of indigenous peoples, places and practices, usually by showcasing cultural resilience, territorial integrity, political determination, and economic necessity. Characterized by a capacity to 'shape counter-discourses and engender alternative public spheres, ${ }^{2}$ indigenous videos contribute to ethnopolitical struggles to transform state-society relations, reconfigure national identities, and redefine development. To undertake their oppositional cultural work indigenous media makers 'revisit, contribute to, borrow from, critique, and reconfigure ethnographic film conventions, at the same time operating within and stretching the boundaries created by these conventions.' Michelle Raheja observes how this appropriative exchange creates and occupies a 'space between

\section{Corresponding author:}

Laurel C. Smith, Department of Geography and Environmental Sustainability, University of Oklahoma, 100 East Boyd St, SEC 684, Norman, OK 7307I USA

Email: laurel@ou.edu 
resistance and compliance.' She conceptualizes their visual practices as 'visual sovereignty' and argues that with this methodology indigenous filmmakers draw upon and deconstruct 'whitegenerated representations of indigenous people.' The hybridity of indigenous media makers' visualizations allows them to intervene on behalf of 'indigenous cultural and political power both within and outside of Western legal jurisprudence. ${ }^{3}$ Visual sovereignty is one of many indigenous methodologies designed to decolonize knowledge production. Messing with colonial categories and related research conventions in this way helps to undermine stereotypes. It also encourages researchers to learn how not to see with 'imperial eyes." 4

Inspired by this decoloniality, I have argued elsewhere that indigenous video is a post-colonial technoscience characterized by multiple sites of coproduction and transnational circuits of exhibition. $^{5}$ Like any technoscientific intervention, such hybrid knowledge production is situated. Indigenous videos grow out of specific organizational geographies, marked by particular intellectual genealogies. For example, although crafted to challenge the visual economies created in the colonial era and continued by Latin American states, many indigenous media projects emerge out of cultural programming orchestrated by reformers working in state institutions during the late 1980s and 1990s. Since that time, state support for indigenous video production has dwindled. But individual artists, local and regional organizations, and transnational coalitions arose out of, and continue to be buoyed by, intellectual and institutional currents similar to those that designed and delivered government programs. Comprised of people who self-identify as indigenous and those who don't, these media collectives operate pragmatically in pursuit of the production and dissemination of indigenous media. Sometimes they work apart from, and other times alongside, various state agencies. ${ }^{6}$

In this article, I study the unruly cultural geographies of hybrid knowledge production by situating an indigenous video titled Dulce Convivencia/Sweet Gathering. This 18-minute video documents traditions practiced in the community of the Mixe man from Oaxaca, Mexico who made it. Before going further, I should disclose that I have known the video maker, Filoteo Gómez Martínez for longer than a decade; we've been married for almost nine years; we share computers, cameras, a home, and a son. Like his family, friends, and associates, I call him Filo. Filo entered the organizational arena of indigenous video production after we married, and his acquisition of video skills overlapped with my longitudinal ethnographic study of indigenous media making in Oaxaca. The consequential ethnographic intimacy may make some readers uncomfortable. Our proximity underscores how speaking for others entails selective silence and - ideally - intensifies expectations of fidelity and accountability. Given my circumstances, I avoid asserting a masterful meaning of Dulce Convivencia; rather, I aim to tell the most polyvocal story I can about Filo's video.

To do this I begin with diffraction, Donna Haraway's cyborgian strategy of visualization. ${ }^{7}$ To suggest how this concept helps to decolonize hybridity, I review how Haraway formulates diffraction by telling two overlapping stories about a photograph of an indigenous man videotaping. Then I explain how and why I take Haraway's methodology of diffraction a step further. Instead of juxtaposing two readings that could be construed as binaries, I draw on a decade of ethnographic inquiry to articulate Dulce Conviencia from three different perspectives. I start by examining the reception of Dulce Conviencia at festivals focused on indigenous media. Festival audiences laud Filo's representation of place-based indigeneity as a celebration of belonging and collective selfreliance. But they can't see the geographies of its production. I address this gap with a geographic analysis of Dulce Convivencia. I locate the hybrid knowledge production practices that gave rise to Filo's video, and trace the transnational circuits of exhibition that continue to shape its travels. Another scholar's argument that the video romanticizes indigenous communities initiates the final 'take' on Dulce Convivencia. Filo responds to this critique by identifying his target audience and 
explaining how and why he tailored his video for these viewers. His response politicizes his mediation of place in ways not visible in the first two interpretations.

After this three-part story I consider the diffraction among these three understandings of Dulce Convivencia. One video can have many meanings and it is difficult to prioritize one valuation over others. They all matter in different ways; plus the entanglements among these meanings and values make it impossible to isolate them from one another. Diffracted stories contribute to the decolonization of hybrid knowledge production by not only revealing disconnects, but also common - and uneven - grounds.

\section{Hybridity}

Given how collaboration in the name of decolonization is inherent to the production of indigenous videos, the concept of hybridity seems ideally suited to the task of sketching the contours of indigenous video. The theoretical relocations of hybridity highlight the transgression of colonial categories of analysis and administration. They also disrupt hegemonic formulations of nation and race. At its best, hybridity problematizes sites/cites/sights of power, knowledge, and visibility with an insistence on impurity and mingling. ${ }^{8}$ Hybridity has been especially useful for conceptualizing the technoscientific geographies that complicate nature-society relations. Regardless of its theoretical leverage, however, when not informed by everyday socio-economic relations and the geopolitical positions shaping them, notions of hybridity lend themselves to commodification, racialization, and state cooptation. ${ }^{9}$ Hybridity claims require caution, especially when discussing indigeneity.

The usefulness of hybridity for reactionary forces is particularly pronounced in Latin America, where popular and state notions of nationality tend to celebrate a mestizo heritage. Postindependence discourses and material manifestations of mestizaje envision the future by valorizing indigenous peoples' glorious past and heroic resistance to the Spanish. This biological story of origins positions indigenous peoples, especially indigenous women, as patrimony. ${ }^{10}$ It also justifies inequalities and underwrites indigenismo, the drive for cultural assimilation that imbued institutional efforts to engineer modern nation-states. With this conceptualization of hybridity, technocrats sought to diagnose the ailments of indigenous populations and then remedy the differences identified as prohibitive to progress. ${ }^{11}$ More recently, throughout Latin America these national narratives meld with neoliberal multiculturalism. Branding place with a depoliticized and picturesque folkloric present designed to promote tourism allows indigeneity to be seen by states, corporations, and consumers as more natural or primitive, alluring but not threatening. This limits contemporary indigenous actors' agency and options by establishing expectations of authenticity and then accusations of invention and illegitimacy. ${ }^{12}$

Given the risks of hybridity, how best to examine, describe and discuss the collaborative practices of visualization and the overlapping organizational geographies of indigenous video production? Donna Haraway's figuration of the cyborg provides a path for moving forward without forgetting the geopolitical dangers of representing agency. Designed to shake the tenacious hold that biological and cultural essentialisms have on political imaginations, Haraway's cyborg metaphor embodies 'a hybrid concept of community which disrupts the purification of culture and nature into distinct ontological zones, onto which the binary of "human" - "nonhuman" is then mapped. ${ }^{, 13}$ In addition to the way the multiplicity of a cyborg's subjectivity troubles categories in potentially libratory ways, two visual elements make the theorization of hybridity and marginalization inherent to Haraway's cyborg especially useful. One is her refusal to lose sight of technological mediation, and the other is her obsession with the politics of visibility. Without losing sight of struggles over how to see, Haraway locates visual technology as a key actor in the 
assembly of knowledge about what is natural, real and moral. ${ }^{14}$ The second selling point of Haraway's figuration of the cyborg is its view from the margins. Unlike the all-surveying skills of sight so symptomatic of white masculinist socio-spatial epistemologies, ${ }^{15}$ cyborg vision is partial in two senses. It is geographically and culturally specific, which means that particular institutional, political, and socio-economic contingencies inevitably sculpt our translations. And second, such situated sight favors particular aesthetics, ethics, and politics. Cyborgs embody hybrid knowledge productions that deliberately turn the volume up and down in an effort to amplify historically marginalized voices.

\section{Diffraction}

One of the strategies Haraway uses to describe cyborg vision is diffraction. ${ }^{16}$ Cyborgs witness the socio-spatial processes and cultural practices of technoscience from multiple subject positions. Such a complex social geography 'results from and leads to interruption, diffraction and, reinvention. ${ }^{17}$ Haraway explains that:

Diffraction does not produce 'the same' displaced, as reflection and refraction do. Diffraction is a mapping of the interference, not of replication, reflection, or reproduction. A diffraction pattern does not map where differences appear, but rather maps where the effects of difference appear . . . the first invites the illusion of essential, fixed position, while the second trains us to more subtle visions. ${ }^{18}$

Unlike reflections, which purport to mirror reality, diffractions describe interdependency and disruption as well as continuity. To show us a 'diffracted narrative,' Haraway tells a 'simple . . story based on little differences. ${ }^{19}$ She structures her analysis with two ways of seeing a photograph of a Kayapo man videotaping Kayapo communities' protest of a massive dam project in Brazil.

Her first look at the photograph operates with the epistemological assumption that:

The represented must be disengaged from surrounding and constituting discursive and non-discursive nexuses and relocated in the authorial domain of the representative ... [and] ... the represented is reduced to the permanent status of the recipient of action, never to be a co-author in an articulated practice among unlike, but joined, social actors ... The authorship rests with the representor, even as he claims independent object status for the represented. ${ }^{20}$

From this point of view, this man has no agency of his own; rather, the viewer authoritatively interprets his actions. Haraway calls this optics of theory the 'political semiotics of representation' and she operationalizes it thus:

The National Geographic Society, Discover magazine, and Gulf Oil - and much philosophy and social science - would have us see [the Kayapo man's] practice as a double boundary crossing between the primitive and the modern. His representational practice, signified by his latest technology, places him in the realm of the modern. He is, then, engaged in an entertaining contradiction - the preservation of an unmodern way of life with the aid of incongruous modern technology. ${ }^{21}$

This image of a human and his seemingly surprising use of a video camcorder offers an exotic juxtaposition that fascinates many viewers. The transgression of cultural categories demarcated by teleological ideas about the technological progress - development - of humanity is regularly a best seller. 
To illustrate how this commercialized and category-driven story denies the Kayapo man's visual agency, Haraway moves on to her second narration. Here she seeks to sidestep the slippery slope of representation by approaching both the Kayapo man and his camera as actants, i.e. 'collective entities doing things in a structured and structuring field of action. ${ }^{22}$ To do this Haraway assumes a line of vision focused on connections instead of categories. 'From [this] perspective of a political semiotics of articulation,' observes Haraway:

... the man might well be forging a recent collective of humans and unhumans, in this case made up of the Kayapo, videocams, land, plants, animals, near and distant audiences, and other constituents.

Looking for, and working with, such linkages makes things appear different(ly) - mostly because we (viewers, analysts, readers, etc.) are involved. Haraway explains:

... meanings have to be approached differently, in terms of the kinds of collective action taking place and the claims they make on others - such as ourselves, people who do not live in the Amazon. We are all in chiasmatic borderlands, liminal areas where new shapes, new kinds of action and responsibility, are gestating in the world. The man using that camera is forging a practical claim on us, morally and epistemologically, as well as on the other forest people to whom he will show the tape to consolidate defense of the forest. His practice invites further articulation - on terms shaped by the forest people. They will no longer be represented as Objects, not because they cross a line to represent themselves in 'modern' terms as subjects, but because they powerfully form articulated collectives. ${ }^{23}$

Instead of seeing a spectacle of crossed boundaries, Haraway's second look at this man and his camera seeks to initiate and foster accountability and action formulated 'on terms shaped by the forest people. ${ }^{24}$ Like Haraway, I think this is an important shift in investigative focus because it decolonizes knowledge production by investing an indigenous actor with potent agency. This theoretical move fosters political kinship.

Don't be fooled, however; Haraway's theoretical tale aims for much more than a mere good viewpoint/bad viewpoint comparison of audiences. Because it is told with a cyborg's 'double vision,' the moral of this twice-told story about a photo of an indigenous man with a video camera emerges not only through contemplation of the differences between the two narratives, but also through their diffraction. While the first view is problematic, it does help to suggest why '[i]ndigenous people are resisting a long history of forced "tutelage". ${ }^{25}$ It demonstrates how institutions and individuals with headquarters and homes generally located far beyond the communities providing the 'data' or 'resources' or 'problems' for 'authoritative' inquiries into, and analyses of, matters of life and death have represented indigenous geographies. Indeed, the material and discursive impacts of such epistemological practices have been, and remain, daily influences on the lives of people who position themselves and/or are positioned by other actors as indigenous.

Haraway's second visualization seeks to avoid colonialist representational practices. Instead of starting with and then solidifying identity categories, this perspective focuses on process and a more fairly distributed sense of agency. Yet, even though Haraway's second reading of the photograph suggests he's poised to do a lot of potential good, not every audience - perhaps not even the man with camcorder - will see eye-to-eye with Haraway's attempt to avoid the essentialist tendencies. For many indigenous actors involved in struggles over territory and resources, identity categories serve as political platforms, their colonialist origins be damned. And that's the whole point of diffraction. Not everyone yearns to know about the same things. Rather than painting a complete picture without coloring outside distinct borders, Haraway's two-part story about indigenous video offers a more 'subtle vision' whereby the two narratives interact. The reverberations caused by 
their intersection trace an uneven geopolitical terrain where it's difficult to envision cultural resilience without an essentialized sense of indigeneity - perhaps because this is the lens through which many video viewers and media makers see indigenous communities.

Additionally, ethnographic knowledge of uneven access and the privileges of participation would surely complicate Haraway's twice-told story even more forcefully. In the following I illustrate this point with a three-part story about Dulce Convivencia. The first part examines the video's reception at film festivals. It resembles Haraway's 'political semiotics of representation' because festival viewers see the video in terms of place-based categories of cultural origins. The second part speaks to Haraway's call for a more hopeful 'political semiotics of articulation.' It records the geographical and intellectual movements that made Filo's representation of place possible and well traveled. The third part draws on ethnographic knowledge to center Filo's motivation for making Dulce Convivencia. This augments Haraway's two-prong story-telling strategy with a 'political semiotics of intervention.' Bringing this third point of view into the picture intensifies awareness of the geopolitics of hybrid knowledge production. But before launching into my three-part diffracted story about Dulce Convivencia, I need to summarize the video's content. ${ }^{26}$

\section{Dulce Convivencia}

A filmmaker's focus on the production of panela (raw brown sugar) in his hometown in Oaxaca provides insight into the strength and rewards of the indigenous way of life. (Description of Dulce Convivencia found on the Smithsonian's National Museum of the American Indian website, Native Networks ${ }^{27}$

The opening shot of Dulce Convivencia features Filo, the video maker, seated in front of an adobe wall. Addressing viewers in Mixe, he explains that after being away from his community he returned with a camera to record the process of producing panela (an unrefined cane sugar). He speaks over a montage of photographs of a young boy 'recording' with half a discarded hand mill food grinder and then appealing to an adult feeding sugar cane into a trapiche, a large wooden mill. Filo tells viewers that he wants to share what he saw when he recorded, and how people reacted to being recorded. When the montage ends we see Filo again. He lifts a remote control, points it off camera, and says, 'Let's roll!'

The video's title appears superimposed first over the trapiche and then over a close-up of the expressed sugar cane juice bubbling as it boils. Next is a series of shots featuring a man and a woman individually speaking to the camera. Their words also provide voice-over during scenes of people packing up, traveling to, arriving at and settling into the rancho, or field hut where they stay during the sugar cane harvest and processing. Among other things, the man points out that no one is obliged to copy what comes from outside, but there is an obligation to conserve both inherited practices and natural resources; the woman compares the unknown dangers of refined sugar to the familiarity and everyday use of panela. Following this introduction to panela, the sugar cane harvest and panela production process takes place on camera. We see men, women, children, and grandparents working together while ambient sounds fill the soundtrack. Birds sing and insects buzz; mules munch; steel blades cut; juice boils and gets stirred in large tubs set into hillside ovens with roaring fires. Recorded whistling and foot tapping (by Filo's father) also accompanies these scenes. There is no narrator. Instead the people chat with each other and talk with Filo, who jokes from behind the camera and samples a lump of the solidifying panela that someone offers him. Sometimes the conversation is subtitled (in English or Spanish), other times it's not. 
After we see large tubs scraped empty and wooden molds filled with the boiled sugar, the man interviewed earlier reappears. He observes that many people just fill their stomachs without knowing anything about what they eat. Filo then speaks about the virtues of panela during a slow motion shot of his hand holding a dried cone of the sweetener. Shots of panela wrapped in plant leaves and stored on a shelf over a cooking fire follow. Women make tamales, prepare coffee with panela, and serve others who have gathered for a meal. As these final scenes unfold Filo tells viewers that:

'Convivencia' is the way of life in indigenous communities. Where everyone shares the work, the good times and the suffering, while respecting each other. These are the main reasons why we can carry on as a community. This is what has allowed us to survive as indigenous peoples. Sweet is working together, even though the work is hard. That's what I call 'Dulce Convivencia': the sweetness of living together.

Next we once more see Filo seated in front of the adobe wall. He thanks the viewers and says he appreciates the time taken to view the video. Then the credits roll alongside the grinding trapiche.

\section{Representation}

In this first of three examinations of Dulce Convivencia, I draw on the reviews of others to discuss its reception at a series of film and video festivals geared toward indigenous media. Comprised of selection and award juries, screening attendees, and renters of related DVD collections, festival audiences see beauty and belonging in Filo's video. These viewers identify Filo as a community insider and herald his video's genuineness. They agree that his video truthfully and artfully represents a place-based practice of collective labor. In its images and sounds they find valuable lessons about all kinds of sustainability.

Dulce Convivencia has been well-received by festival audiences since its festival debut in November 2005 at Geografias Suaves: CINE/VIDEO/SOCIEDAD, a regional event in Mérida, Mexico, where it won the Bichito de Maiz for best work spoken in an indigenous language. The following year it won the same honor at the International Cherokee Film Festival in Talequah, Oklahoma. It was also one of five works selected to receive Best Work recognition at Raiz de la Imagen, the eighth film and video festival of the Coordinadora Latinoamericana de Cine $y$ Comunicación de los Pueblos Indigenas (CLACPI) held in the capital city of Oaxaca during the summer of $2006 .{ }^{28}$ The award jury at the CLACPI festival described its reasoning for recognizing Dulce Convivencia as a Best Work:

For the lyricism and the sensitivity with which the author approaches the community, which is represented not only in the beauty and simplicity of his images, but also in the positive and lucid spirit that emanates from the values expressed in collective work, environmental relations, and the traditional productive processes of agrarian peoples. ${ }^{29}$

Subsequent festival audiences offer similar assessments of the video maker's notable proximity and artistic rendering of authentic place-centered communal practices. Their reviews echo Filo's concluding comments about the collective labor being the key to survival.

In an overview of the Los Angeles installment of the National Geographic Society's All Roads Film Festival ${ }^{30}$ published in the January 2007 issue of Documentary Magazine, contributing editor Taylor Segrest describes Dulce Convencia as a 'minor masterpiece.' He identifies it as the 'most powerful film in the festival ... [It] demonstrates how a straightforward subject (making panela, or unrefined sugar) can be treated with such understated reverence as to become a visionary 
experience.' With its transcendent aesthetics and earnest narrative, Dulce Convivencia captures the flavor of the All Roads Festival. Segrest says it embodies the festival's 'definitive theme,' which he identifies as 'indigenous cultures in conflict with modernity.' Because of the 'deeper respect and appreciation for their subject' that characterize its 2006 selections, Segrest positions the All Roads Festival at 'the forefront of an emerging indigenous filmmaking movement.' This media movement '. . . aims to utilize modern tools to proliferate awareness about some of our planet's most enduring ways of living as expression, as document, as celebration, but also, in some cases as lastsecond flare.' Segrest ends his examination of the All Roads festival by referencing Filo's video in his final observation that " $[\mathrm{i}] \mathrm{n}$ all these documentaries, dulce convivencia can be tasted in one form or another - sometimes as a yearning, sometimes as a memory, but always there . . .31

Given Segrest's melancholy reading of some of the festival selections as signals shot from sinking ships, it is not surprising that he situates the media screened in the festival as a 'new and improved' sort of salvage ethnography. Pursued by community insiders, these mediated performances of place displace 'the ethnographic middleman.' Noting that the festival director told him the All Roads Project's original mission was, and remains, presenting such material to 'mass audiences,' Segrest argues that the works screened during this event aim to foster greater respect for cultural differences among non-indigenous viewers. Segrest connects the festival forum and Dulce Convivencia to larger movements pushing for greater indigenous self-representation.

Similar appreciation for the aesthetic merits of Dulce Convivencia and assumptions about its target audience inform a review composed by someone who watched the festival collection in his home. In April of 2009, Portland-based writer and university instructor Dennis Grunes came across Dulce Convivencia when he watched disc one of the 3-DVD set titled All Roads Film Festival Collection 2, which he had rented from Netflix. Afterward he posted his reading of it in the archive of film reviews on his blog. He begins with the following observations about audience, community, and labor.

Despite the title, which reflects the wider audience that the filmmaker hopes to affect and educate, Dulce Convivencia is in Mixe, the language of director-cinematographer Filoteo Gómez Martínez's indigenous rural village, San Miguel Quetzaltepec in Oaxaca, Mexico, to which he has returned with camera in hand to document the process by which panela is made (it is used in beverages and desserts), beginning with the planting of sugar cane. Gómez has dedicated his film to those we see: parents, relatives, neighbors, all of whom he lists and - the word should take on deeper meaning here - credits. Although most of the film unobtrusively observes, someone along the way notes, 'In our village we learn by helping.' They share the work and respect one another. ${ }^{32}$

According to Grunes, the Spanish title suggests the video targets an audience located outside Quetzaltepec. Furthermore, Filo's insider status allows him to unobtrusively document how collective work fosters mutual respect and enables greater self-sufficiency in his home community.

To emphasize the video's authenticity, Grunes points to the video's start, when Filo addresses the camera.

Young Gómez - at the beginning of his film he faces us - makes documentaries that show indigenous peoples in their normal lives. Here, he gives two aims for his film: to show not only the panela that is being made, but also the villagers' reactions to the camera. The kid is being sly and wry; there is no reaction, only total acceptance and appreciation - a reciprocation of his attitude and spirit.

The villagers are traditional. A few persons say what is on their minds. People today generally don't think about what they eat; they fill their bellies often not knowing the ingredients in their meals. These people raise their own food and prepare their own meals. The word self-sufficiency crops up. 
But it is images of labor that are most memorable: the cutting of the cane; the grinding it in a trapiche, a home-built sugar press. And the aura that is there in the village: the sense that the best thing for one person to do is to help everyone else.

According to Grunes, the video successfully achieves Filo's first aim; he truthfully portrays panela production. The second aim Filo articulates is read as a joke. There is no discernable reaction to his recording of everyday practices. The video directly mirrors socio-economic and cultural practices in Quetzaltepec.

Echoing the other assessments, Grunes's review of Dulce Convivencia suggests that the video's undistorted vision of communal ties established and maintained through collective labor offers viewers alternatives to the alienation of individualism and unsustainable patterns of globalized consumption. Filo's representation of Quetzaltepec seems to stir a yearning for sustainability and survival. Festival viewers correlate Filo's plain and direct story-telling style in Dulce Convivencia with a naturalist aesthetic. Eschewing flashy editing for a steady-paced and logical sequencing of uncomplicated shots, mostly relying on a still camera, and focusing on natural sounds allows Filo to reveal his community's reality.

I shared this assessment, until a gradual accumulation of evidence suggested that a 'politics of representation' that dwells on the video's simplicity and straightforwardness fails to consider how Filo's 'pure' vision manipulates viewers. While working with Filo to archive the still photographs he took during his video shoot in Quetzaltepec, I eventually realized that he had accompanied and recorded two different extended family groups' sugar cane harvest and production of panela. Carefully sutured footage and viewers' unfamiliarity with the residents of Filo's pueblo prevents most audiences from seeing this. Furthermore, one group visible in Filo's photographs used a metal mill for grinding up the cane and plastic pails to hold the liquid cane juice as it cooled and solidified into panela. While we see the people from this group in Filo's video, we don't see their implements. Like many documenters of indigeneity, Filo excised machines, along with plastic. His aim, he says, was aesthetic and culinary. Not only is the wooden sugar press more striking visually and audibly, but according to Filo many people from Quetzaltepec are convinced that a trapiche and wooden molds produce the 'true taste' of panela. Filo also had political reasons for crafting his vision of communal labor in the way he did, but before addressing those, I want to flesh out further the geographies of access and mobility that gave rise to Dulce Convivencia.

\section{Articulation}

The festival audience identified above celebrated Dulce Convivencia as a text that captures the sense of place and the spirit of belonging to an indigenous community. This second look at the video dwells on the video's context. Out of concern that festival audiences miss the multiple ways indigenous videos mediate place, I want to contextualize the video with a narrative that focuses on intellectual exchange and technological support. My point in sharing this story about mobility and access is not to celebrate contingency (although its powerful influence must be recognized), but rather to underscore how Filo's representation of place and the sweetness of belonging arose out of collective reflection, as well as his individual experience.

Growing up in San Miguel Quetzaltepec, a Mixe community in the Sierra Norte Mountains of Oaxaca, Filo helped with the seasonal chores that distinguish his family's agricultural life. His family sent him to the capital city of Oaxaca to continue his studies. ${ }^{33}$ After high school, Filo remained in the capital to work, acquire some computer skills, and improve his Spanish. He also began to learn English, sometimes in classes, but most often in conversations with the tourists from 
many parts of the world. In September 2000, I met Filo through the hostel where he worked. He discovered video more than two years later. After our wedding in May of 2003, Filo starting using a mini-DVD camcorder I had purchased the year before with a research grant. He liked it, so I suggested he consider attending an upcoming workshop offered by some of the people I was interviewing.

That summer Filo used our camcorder to participate in the second of a series of visual media workshops collected beneath the title of Mirada Biónica/Bionic Gaze. A trio of media makers based in the capital city of Oaxaca coordinated these events. They drew upon their professional and personal relationships with artists, state and municipal agencies, and also a collection of media organizations to access equipment and space for screening, discussing, and teaching participants to design, record, and edit a video. Through his Mirada Biónica experience, Filo accessed an organizational geography through which he met several indigenous, documentary, and/or experimental video makers. He also tapped into some pivotal places.

For instance, to create his first video (about our dog), he relied upon equipment housed in the Centro de Video Indigena (CVI), which had been established by the Instituto Nacional Indigenista (INI) in 1994. Not long after the start of President Fox's administration, INI became the Comisión Nacional para el Desarrollo de los Pueblos Indigenas (CDI) and the CVI was downsized from a two-story residential home to office space above a hardware store. During his first Mirada Biónica workshop in 2003, Filo had met the director of the CVI while working in this institutional place. A couple months later, the director of the CVI invited Filo to represent Oaxaca at a CDI sponsored workshop on indigenous video convened from late October through December, partly in Ixhuatlancillo, Veracruz. Initially a young woman who had been working on projects at the CVI had been invited, but her parents wouldn't allow her to attend the three-week out-of-state portion of the national workshop. Filo, on the other hand, was able to take advantage of this opportunity for state support.

This state sponsorship introduced Filo to even more academic advocacy and related indigenous activism. During the CDI workshop, Filo worked with the CVI director and two other young men from Oaxaca to produce a video titled UKEN KE UKEN y La Gotzona Educativa. Their video explored the efforts to revitalize the Zapotec language and traditions through the establishment of a cultural center in Yalálag, a pueblo in the Sierra Norte region. ${ }^{34}$ Featured in this video are scenes of a bedridden Juan José Rendón Monzón, a Mexican anthropologist who had facilitated the formation of ethnolinguistic projects in Oaxaca. Rendón Monzón speaks about comunalidad, a concept he and indigenous intellectuals from the region had formulated. As he explains in the video (and in his written work), comunalidad refers to the social cohesion characterizing indigenous communities that is created and fostered by collective practices of labor and celebration. Another key theorist of comunalidad is Jamie Martínez Luna, a Zapotec intellectual who represented the selection jury when Filo's video Dulce Convivencia was recognized with a Best Work award at the CLACPI festival in $2006 .^{35}$

In addition to unfolding in the state-run Center for Indigenous Video, the Mirada Biónica workshops also took place in the Universidad de la Tierra (known as the Unitierra), an alternative education center in the capital of Oaxaca run by post-development guru Gustavo Esteva and his associates. ${ }^{36}$ After learning about the Unitierra through Mirada Biónica, Filo participated in a social communications program it offered. He attended seminars and screenings there as he edited his video about the production of panela in San Miguel Quetzaltepec. It seems to me that in addition to comunalidad, Dulce Convivencia evokes one of the key themes discussed at this alternative education center: the concept of conviviality as described by the Austrian scholar Ivan Illich. ${ }^{37}$ Illich's use of the term adds to the notion of a friendly, festive, and food-oriented gathering (i.e., a convivial) a strong sense of long-term communal and environmental commitments from which 
industrialization and professionalization alienate people. In fact, Filo says he was reading a Spanish translation of Illich's 1973 book Tools for Conviviality as he edited footage into Dulce Convivencia.

Another part of Filo's studies at the Unitierra was an internship with Ojo de Agua Comunicación, the media organization central to my investigation of indigenous video production. The fieldwork portion of my study ended when I returned to the US in August 2004. But since Filo could not yet legally enter the United States, he remained in Oaxaca and eventually became a full-time member of Ojo de Agua. Working with this fluctuating group of about eight people, half of whom selfidentify as indigenous, expanded Filo's horizons. He traveled in Mexico and beyond to participate in video production projects as well as seminars, workshops, and festivals concerned with indigenous cultural and civic activism. ${ }^{38}$ Ojo de Agua provided Filo with creative and technical camaraderie as he created Dulce Convivencia. This organization also facilitated his video's post-production and subtitling, as well as its duplication and distribution through channels of exhibition that welcomed indigenous videos. As demonstrated in the first representation of Dulce Convivencia, Filo's place-centered story of community cohesion pleased festival selectors, juries, and viewers. ${ }^{39}$ In addition to the venues mentioned in the first story, it screened at the National Museum of the American Indian's Indigenous Film and Video Festival, and was exhibited during the Museum of Modern Art's Annual Festival of Nonfiction Film in New York City. It was also shown during festivals in several Latin American countries, Canada, France, and Nepal.

Although these festival events screened Filo's video and championed indigenous media as cultural activism, to my knowledge they never sought to embed Dulce Convivencia or its maker within the state sponsored initiatives and transnational intellectual currents characterizing Oaxaca's civil society. An unintended consequence of this lack of contextualization is the obfuscation of intellectual co-production. Furthermore, failure to connect indigenous activism with the oftenacademic advocacy that helps mobilize it fosters a tendency to lose sight of state strategies of containment. Stimulated by Haraway's 'politics of articulation,' my study of how Filo encountered ideas and accessed machines highlights knowledge exchange. It also brings the state back into view; however, the state appears as a source of benign support for technology transfers, workshops, and symposia. In the following story, I listen to Filo's reasons for making Dulce Convivencia and learn to see a more shadowy state. ${ }^{40}$

\section{Intervention}

The previous story about the making of Dulce Convivencia narrates an academic argument for approaching indigenous videos as technology-mediated co-productions of indigeneity that arise out of contingencies, personal connections, and specific organizational geographies. But not all scholarly viewers will share my hopeful fascination with collaboration or so easily forgive the romanticism evident in the concept of comunalidad, Filo's video, Ivan Illych's work, and transnational cultural advocacy. And as this final story demonstrates, ample evidence justifies such reservations. The most recent upheavals transforming regional political economies don't just restructure states, they also reconfigure indigenous communities in ways that further challenge collective practices and complicate visions of self-sufficiency. Such geopolitical complexity becomes more visible when Filo situates his cultural work.

In November of 2005, I was in Oaxaca visiting Filo and accompanied him on a trip to Xalapa, Veracruz for a symposium that brought together scholars and media activists. ${ }^{41}$ As a representative of Ojo de Agua, Filo participated in this forum for hybrid knowledge production and exchange by giving an overview of indigenous video making in Oaxaca. Also in attendance was Josefina Fernández, an Argentinean anthropologist who gave a scholarly paper titled 'Cuerpos Desobedientes' 
[Disobedient Bodies], in which she discussed transgendered communities in Buenos Aires. ${ }^{42}$ Dulce Convivencia was screened the first evening. When the lights came up and a microphone appeared, Fernández was the first to speak. She critiqued Dulce Convivencia as an overly folkloric and therefore disempowering documentary. As proof of the video's failure to transgress hallowed but retrograde assumptions that indigenous communities live in harmony with their environments, she pointed out the 'naturalistic soundtrack' featuring birds, rushing water, and whistling. You could have heard a pin drop in the small cinema as Fernández handed the microphone back to the moderator. All eyes turned to Filo. At the time he had little to say. He thanked Fernández, observing that her critique helped him see Quetzaltepec and his video in new ways. And then, before handing back the microphone and sitting down, he noted that he had tailored Dulce Convivenica for an altogether different audience.

Since then, I have asked Filo about his response to Fernández. To answer to my queries, he usually begins by reminding me that he undertook this video project after a seven-year absence from his pueblo that was punctuated only by occasional, brief visits. When he traveled back there to record the panela harvest, he says he returned not only with our mini-DVD camcorder, but also with the idea that video could serve as a mirror in which the community might see itself. Sensitive to how easily he might be received as an inexperienced upstart who had gone to the city, acquired an education, and then returned to offer unsolicited advice, Filo figured his audience of Quetzaltepecanos merited the utmost respect. In no way should his video shock, scold, or lecture. Focusing on the images, sounds, and rhythms he thought his family and neighbors, young and old, would most like to see, he recorded a common practice of working together in a peaceful and productive manner. His hope was (and is) to spark collective reflection among the residents of Quetzaltepec about place-specific traditions that fostered collaboration. This way Dulce Convivencia might contribute to community conversations about the current situation, recent events, and a communal future.

Furthermore, when he went home to record panela production, Filo says he saw Quetzaltepec with new awareness of the conflicts creating contentious changes there. Shortly before accessing video technologies and training in the summer of 2003, Filo had returned to Oaxaca after seven mostly miserable months living and trying to work without legal documentation in Milwaukee, Wisconsin. Since I was still obliged to be in Oaxaca during this time, we relied on the telephone, and then email, to stay in touch and plan a mutual future. These media also allowed me to keep Filo informed about his cousin, Gregorio Ramírez Aguilar, who had been elected Municipal President in November 2001. This position put Filo's cousin in charge of the entire area comprising the municipio, an administrative unit akin to a county in the USA, of which the community of San Miguel Quetzaltepec is the county seat.

Gregorio gained this office through a hotly contested election that, for the first time in this community's history, featured two separate polls. The Federal Election Institute chose to honor the results of the vote organized by regional political bosses with close ties to the PRI, Mexico's dominant political party. ${ }^{43}$ Gregorio had not worked his way up the ladder of social service distinguishing the traditional modes of local governance that men are expected to climb before getting named to this position by the community. ${ }^{44}$ This failure to observe local protocol compounded local dismay about the intensified meddling by political parties in community affairs, and exacerbated the reluctance of many residents to accept Filo's cousin as municipal president when he took office in early 2002.

A year later, rising tensions, both within Quetzaltepec and throughout the entire municipio, led to Filo's cousin being jailed in a nearby agencia, a settlement within a municipio, in mid-May. The authorities had put Gregorio in jail to protect him from angry residents, who accused him of failing to disburse the municipal resources earmarked for this and other agencias. ${ }^{45}$ After his release was 
brokered by state officials, Gregorio fled to the capital city of Oaxaca. When their store and home in Quetzaltepec were ransacked and burned, his parents soon joined him. A couple weeks later, Filo and I returned to Oaxaca as newlyweds. We took up residence in the capital city and worried as conditions deteriorated in Quetzaltepec. Armed groups clashed over claims to the municipal Presidency. Such confrontations resulted in several deaths, including that of a young man with whom Filo had delivered newspapers while he was a student in Oaxaca. Meanwhile, based in the capital with his family, Gregorio served out an unprecedented three-year term as municipal president, doing little regarding community affairs, but still receiving a salary from the state government headed by a PRI governor. ${ }^{46}$

While he engaged with video workshops and study programs and discussed the current situation with his parents during brief visits to Quetzaltepec, Filo says he began to embed the event within larger patterns of conflict and change. The decentralization of power undertaken as part of the neoliberal adjustments pursued by the Mexican government granted municipios more direct access to funds. This enhanced the ability of local decision makers to utilize these resources as they saw fit, which has heightened political parties' interest in municipal governance. Furthermore, in Oaxaca the modification of the state constitution to legally recognize usos y costumbres, traditional forms of governance practiced by most indigenous communities, has fortified the authority of municipal administrations. ${ }^{47}$

Filo sets these local manifestations of state reforms alongside the ways that growing religious diversity in Quetzaltepec helps to dismantle systems of community governance and social service. As in many indigenous regions of Mexico, the individualism and other forms of isolation imported by evangelical churches and Jehovah's Witnesses challenge communal practices of governance. ${ }^{48}$ Additionally, the influx of consumer culture, fueled by increasingly accessible mass media, migrants' remittances, and related fantasies about the American Dream, feeds discontent among youth. Filo connects these new cultural resouces to the shame he felt when he first arrived in the capital and heard co-workers, classmates, and kin criticize how he dressed and talked, especially if he spoke Mixe. All of these transformations and troubles were on Filo's mind when he returned to Quetzaltepec to document the production of panela during the summer of 2004 and when he later sorted through and edited the footage he recorded. He was also struggling to reconcile the respect and admiration with which he had viewed his extended family members with a growing realization that his cousin was building a new home for his family in the capital city. All too clearly Filo saw they had nicely profited from the whole fiasco.

These geopolitical intersections shaped Filo's efforts to represent the practice of collectively producing panela. With a gentle reminder of this tradition, he sought to provide an antidote for ailments afflicting his pueblo. ${ }^{49}$ Not anticipating the great distance his video would travel, the diverse ways various audiences have seen Dulce Convivencia initially caught Filo off guard. Now he says he is far more appreciative of how his video can be understood differently. His concerns about being viewed as an upstart speaking out of turn, however, have not changed. Although he finds it difficult to avoid being identified as such, Filo remains reluctant to assume the position of spokesperson for his community, the Mixe region, Oaxaca, Mexico, or indigenous peoples in general. When I ask why, he says he lacks the knowledge [los datos] to presume to speak for others when so much is at stake.

\section{Conclusion}

Determined to provide the most polyvocal analysis possible, and to witness hybrid knowledge production without recourse to binary-bound formulations such as indigenous-non-indigenous and human-machine, I have examined Dulce Convivencia with the cyborgian strategy of 
diffraction. This analytical angle allows me to render Filo's video in three entangled ways. First, festival audiences celebrate its artistic representation of a culturally specific place. While their readings of Filo's video sometimes hint at the 'political semiotics of representation' distinguishing Haraway's first look at the photo of a Kayapo man videotaping, I'm reluctant to dismiss their knowledge production as simply demeaning or entirely inaccurate. Whereas the endearing nature of indigenous social ties is often noted by viewers with nostalgia for what has been lost or is in danger of being lost, Dulce Convivencia doesn't just stir romantic ideas about cultural resistance to commercialization. It also prompts viewer comments on, and questions about, the video's connections to local/slow/organic food movements. I've heard viewers commend the way Filo's video inspires hope by visualizing possibilities for environmental sustainability. In many ways their emphasis on recovery and repair resembles the hopes for cultural sustainability that motivated Filo to make the video.

In the second look at Dulce Convivencia, I seek to emulate Haraway's 'politics of articulation.' By studying the video's making and subsequent movements, I locate the video within organizationally specific and technologically mediated cultural geographies. My analysis demonstrates that the ideas and images found in Dulce Convivencia did not emerge out of nowhere; they did not arise directly from an isolated indigenous man's experiences. Rather Filo's video filters his transnational experiences through theoretical frameworks for identifying and discussing indigenous communities, as well as through fortunate access to technological exchanges. Looking at the roles played by advocates and other activists in visualizations of indigenous geographies highlights the potential of using video projects to co-produce knowledge about risk, responsibility, and vulnerability. Indigenous actors' access and use of this sort of visual technology engenders more inclusive conversations about development, governance, and sustainability. But hybrid knowledge production does not automatically or easily supersede the categorical conundrums of idealism and essentialism that inform the 'politics of representation.' State sponsorship and intellectual and technological collaborations may enable oppositional cultural politics, but that's not the whole story.

The third examination of Dulce Convivencia goes beyond Haraway's dual vision of the Kayapo man's videotaping. To build on her strategy of diffracting a hegemonic, institutional view with a more generous reading of social agency, I take advantage of intimate relations to undertake, and listen to, extended conversations with an indigenous media maker. Filo responds to another academic's condemnation of his video's style by identifying his target audience. In the process of spelling out his aesthetic and political aims, he links his video with all kinds of other geopolitical representation and transnational experience. Despite Filo's faith in video as a mirror that can reflect undistorted representations of reality, his video is no maudlin study of the past. Rather it is a study of a specific communal tradition practiced in Quetzaltepec that Filo created in the hope of intervening from a distance - in the future of a community he still considers his own. Examining Dulce Convivencia from the perspective of the person who made it brings into the picture violent cultural geographies characterized by privilege and state sanctioned corruption.

And yet, those who view the video through festival channels might never know this, much less suspect the geopolitical urgency of its message. All too easily audiences encounter work like Dulce Convivencia in settings such as festivals and museum showcases designed to celebrate indigeneity, tradition, and related notions of naturalism and spirituality. Identifying media makers like Filo as auteurs acting on their own obscures the collaboration and privileged mobilities that make their mediated performances possible. This relatively benign sleight of hand on the part of many festivals fails to provide insight into where others might look for and perhaps tap into the sorts of geographies of access, advocacy, and activism that made video like Dulce Convivencia possible. ${ }^{50}$ Observing these socio-spatial-technological opportunities requires diffracted stories. These sorts 
of stories help us see this larger picture, especially when the stories are told with the benefit of extended ethnographic inquiry into the making and meanings of visualizations like Dulce Convivencia. Indeed, this kind of fieldwork provides common ground for decolonizing scholarly authority. And in turn, diffraction and decolonization facilitate hybrid reconstructions, which in the end are far more insightful and therefore more valuable than expert deconstructions delivered from nowhere.

\section{Funding}

A Dissertation Research Grant (no. SES-0136035) from the National Science Foundation's Science and Technology Studies Program supported portions of the study upon which this article draws.

\section{Acknowledgements}

I love Filo for sharing his life, family, and work with me. I am grateful for the many people in Oaxaca who have kindly and patiently engaged with my endless inquiry. Additionally, this article's articulation of indigenous video as a political intervention is especially indebted to reading Gabriela Zamorano's work (2009, see Note 6), as well as conversations with Gabriela during a workshop in Berlin in February 2011. I thank Helen Robertson and Matt McNair for reading early versions of this paper, and Karl Offen, Bob Rundstrom, Amanda Minks, and Elizabeth Rucker for reading it later. Finally, this text benefitted greatly from the insightful comments and suggestions of Tim Cresswell and two anonymous reviewers. Despite all this support, any awkwardness or errors remain mine.

\section{Notes}

1 Drawing on a growing body of literature focused on indigenous video production in Latin America (see note 6), as well as a decade of conversation with practitioners who claim the title, I use the phrase comunicador indigena [indigenous communicator] to identify media makers from Latin America who self-identify as indigenous and rally communication technologies in order to speak for, and with, communities and other sorts of collectivities to which they belong. In this article, I focus on comunicadores indigenas who record with video and then edit footage into stories with titles and credits.

2 J.F. Salazar and A. Córdova, 'Imperfect Media and the Poetics of Indigenous Video in Latin America', in P. Wilson and M. Stewart (eds) Global Indigenous Media: Cultures, Poetics, and Politics (Durham: Duke University Press, 2008), p. 40.

3 Michelle H. Raheja, 'Reading Nanook's Smile: Visual Sovereignty, Indigenous Revisions of Ethnography, and Atanarjuat (The Fast Runner)', American Quarterly, 59, 2007, p. 1161.

4 For an overview of projects seeking to recognize research as a site of struggle and to reclaim control over the representation indigenous ways of knowing and being by centering indigenous experiences and world views, see Linda Tuhiwai Smith, Decolonizing Methodologies: Research and Indigenous Peoples (London: Zed Books, 1999). To understand how such scholarship entangles with other critical methodologies, see Chela Sandoval, Methodology of the Oppressed (Minneapolis: University of Minnesota Press, 2000); N.K. Denzin, Y.S. Lincoln and L.T. Smith (eds) Handbook of Critical and Indigenous Methodologies (Thousand Oaks, CA: Sage, 2008).

5 Laurel C. Smith, 'Locating Post-Colonial Technoscience: Through the Lens of Indigenous Video', History and Technology, 26, 2010, pp. 251-80.

6 For an excellent examination of colonialist visual economies practiced in Latin America, see D. Poole, Vision, Race, and Modernity: A Visual Economy of the Andean Image World (Princeton: Princeton University Press, 1997). A growing body of research explores the 
emergence and engagements of indigenous video projects in and across different parts of Latin America. See, for example: Lucas Bessire, 'From the Ground, Looking Up: Report on the Video nas Aldeias tour', American Anthropologist, 111, 2009, pp. 101-3; Ana Rosa Duarte Duarte, 'Imaginando a los mayas de hoy: autorrepresentatción y política', Estudios de cultura maya, 32, 2008, pp. 39-62; Carlos F. Flores, 'Video indígena y antropología compartida: una experiencia colaborativa con videastas Maya-Q'eqchi' de Guatemala', Liminar. Estudios Sociales y Humanisticos, 3, 2005, pp. 7-20; Alexandra Halkin, 'Outside the Indigenous Lens: Zapatistas and Autonomous Videomaking', in P. Wilson and M. Stewart (eds) Global Indigenous Media: Cultures, Poetics, and Politics (Durham: Duke University Press, 2008), pp. 160-80; Jeff D. Himpele, Circuits of Culture: Media, Politics, and Indigenous Identity in the Andes (Minneapolis: University of Minnesota Press, 2007); Axel Köhler, 'Nuestros antepasados no tenían cámaras; el video como machete y otros retos de la video-producción indígena en Chiapas, México', Revista Chilena de Antropología Visual, 4, 2004, pp. 391-406; Juan F. Salazar, 'Making Culture Visible: The Mediated Construction of a Mapuche Nation in Chile', in C. Rodríguez, D. Kidd and L. Stein (eds) Making Our Media: Global Initiatives toward a Democratic Public Sphere (Cresskill, NJ: Hampton Press, 2010), pp. 29-46; Salazar and Córdova, 'Imperfect Media'; Freya Schiwy, Indianizing Film: Decolonization, the Andes, and the Question of Technology (New Brunswick, NJ: Rutgers University Press, 2009); Laurel C. Smith, 'Mobilizing Indigenous Video: The Mexican Case', The Journal of Latin American Geography, 5, 2006, pp. 113-28; Smith, 'The Search for Well-Being: Placing Development with Indigenous Identity', in P. Wilson and M. Stewart (eds) Global Indigenous Media: Cultures, Poetics, and Politics (Durham: Duke University Press, 2008), pp. 183-196; Laurel C. Smith, 'Locating Post-Colonial Technoscience'; Terence Turner, 'Representation, Politics, and Cultural Imagination in Indigenous Video: General Points and Kayapo Examples', in F. Ginsburg, L. Abu-Lughod and B. Larkin (eds) Media Worlds: Anthropology on New Terrain (Berkeley: University of California Press, 2002), pp. 75-89; T. Turner, 'Representation, Polyphony, and the Construction of Power in a Kayapó Video', in K. Warren and J. Jackson (eds) Indigenous Movements, Self-Representation, and the State in Latin America (Austin: University of Texas, 2002), pp. 229-50; David M.J. Wood, 'The Metamorphosis of Cine Indigen(ist)a: memoria viva and the Technological Artist in Multicultural Colombia', Latin American and Caribbean Ethnic Studies, 5, 2010, pp. 15373; Erica Wortham, 'Between State and Indigenous Autonomy: Unpacking Video Indígena in Mexico', American Anthropologist, 106, 2004, pp. 363-8; Wortham, "Mas allá de la hibridad": los medios televisivos y la producción de identitdades indígenas en Oaxaca, México', Liminar. Estudios Sociales y Humanísticos, 3, 2005, pp. 34-47; Gabriela Zamorano, 'Entre Didjazá y la Zandunga: iconografía y autorrepresentación indígena de las mujeres del istmo de Tehuantepec, Oaxaca', Liminar. Estudios Sociales y Humanísticos, 3, 2005, pp. 21-33; Zamorano, “Intervenir en la realidad”: usos politicos del video indígena en Bolivia', Revista Colombiana de Antropología, 45, 2009, pp. 259-85.

7 Donna Haraway, 'The Promises of Monsters: A Regenerative Politics for Inappropirate/d Others', in L. Grossberg, C. Nelson and P.A. Treichler (eds) Cultural Studies (New York: Routledge, 1992), pp. 295-337.

8 For instance, see Homi K. Bhabha, The Location of Culture (London: Routledge, 1994); Néstor García Canclini, Hybrid Cultures: Strategies for Entering and Leaving Modernity (Minneapolis: University of Minnesota Press, 2005).

9 Katharyne Mitchell, 'Different Diasporas and the Hype of Hybridity', Environment and Planning D: Society and Space, 15, 1997, pp. 533-53. 
10 For example, see: Ana María Alonso, 'Conforming Disconformity: "Mestizaje," Hybridity, and the Aesthetics of Mexican Nationalism', Cultural Anthropology, 19, 2004, pp. 459-90; Verena Stolcke, 'Los mestizos no nacen, se hacen', in V. Stolcke and A. Coello (eds) Identidades ambivalentes en América Latina (Siglos XVI_XXI) (Barcelona: Edicions Bellaterra, 2008).

11 For example, see: Jose Alcina Franch (ed.), Indianismo e indigenismo en América, (Madrid: Sociedad Quinto Centenario, 1990); Gunther Deitz, 'From Indigenismo to Zapatismo: The Struggle for a Multi-ethnic Mexican Society', in N. Postero and L. Zamosc (eds) The Struggle for Indigenous Rights in Latin America (Portland: Sussex Academic Press, 2004), pp. 32-80; Roberto J. González, 'From Indigenismo to Zapatismo: Theory and Practice in Mexican Anthropology', Human Organization, 63, 2004, pp. 141-50.

12 For example, see: Nancy Grey Postero, Now We are Citizens: Indigenous Politics in Postmulticultural Bolivia (Stanford: Stanford University Press, 2007); Charles R. Hale, 'Neoliberal Multiculturalism: The Remaking of Cultural Rights and Racial Dominance in Central America', PoLAR: Political and Legal Anthropology Review, 28, 2005, pp. 10-28; Carmen Martínez Novo, Who Defines Indigenous? Identities, Development, Intellectuals, and the State in Northern Mexico (New Brunswick, NJ: Rutgers University Press, 2006).

13 Sarah Whatmore, 'Dissecting the Autonomous Self: Hybrid Cartographies for a Relational Ethics', Environment and Planning D: Society and Space, 15, 1997, p. 46; Matthew W. Wilson, 'Cyborg Geographies: Towards Hybrid Epistemologies', Gender, Place and Culture, 16, 2009, p. 511.

14 DonnaHaraway,Modest_Witness@Second_Millennium.FemaleMan@Meets_OncoMouse ${ }^{\mathrm{TM}}$. Feminism and Technoscience (New York: Routledge, 1997), pp. 180-7.

15 Gillian Rose, Feminism and Geography: The Limits of Geographical Knowledge (Minneapolis: University of Minnesota Press, 1993); O. Dwyer and J.P. Jones, 'White SocioSpatial Epistemology', Social \& Cultural Geography, 1, 2000, pp. 209-22.

16 In addition to diffraction, Wilson discusses three other cyborg strategies: witnessing, situating, and acquiring. Wilson, 'Cyborg Geographies'.

17 Haraway, 'The Promises of Monsters', p. 333, n. 18.

18 Emphasis on effects is Haraway, 'The Promises of Monsters', p. 300.

19 Haraway, 'The Promises of Monsters', pp. 309-15.

20 Haraway, 'The Promises of Monsters', pp. 312-13.

21 Haraway, 'The Promises of Monsters', p. 314.

22 Haraway, 'The Promises of Monsters', p. 313.

23 Haraway, 'The Promises of Monsters', p. 314.

24 Haraway builds the foundation of her argument with a thoughtful review of Susanna Hecht and Alexander Cockburn's book, The Fate of the Forest: Developers, Destroyers, and Defenders of the Amazon (New York: Verso, 1989), with which she more fully expounds on the loaded phrase 'the forest people.' Haraway, 'The Promises of Monsters', pp. 309-10.

25 Haraway, 'The Promises of Monsters', p. 310.

26 You can see and hear this video's content thanks to the extraordinary $<$ http://www.isuma.tv $>$, which makes available more than 2000 indigenous films and videos. For English subtitles, search for Sweet Gathering; for Spanish, search for Dulce Convivencia. For an elegant introduction to the cultural work of Isuma Productions, Inc. see M. Raheja, 'Reading Nanook's Smile'.

27 See <http://www.nativenetworks.si.edu/eng/orange/dulce_convivencia.htm> (22 August 2011). 
28 CLACPI was established in the mid-1980s as a forum for exhibiting ethnographic film productions. Since its emergence, CLACPI's composition has come to include many more media makers who self-identify as indigenous. Alongside this demographic change, the transnational organization has turned its attention away from ethnographic production to supporting and celebrating the social processes through which oppositional cultural politics find expression. For a useful overview of this transformation, see Salazar and Córdova, 'Imperfect Media'.

29 Raíz de la imagen. Memoria: un camino de acciones para el cine y video de los pueblos originarios del mundo (Oaxaca, Mexico: Ojo de Agua Comunicación, 2006), p. 77.

30 To learn more about the National Geographic Society's All Roads Film Project, see <http:// events.nationalgeographic.com/events/all-roads/>. These festivals showcase images (photographic as well as moving) of indigenous peoples and other minority populations, many of which are authored by people self-identified along these lines. The first of these festivals took place in 2005, perhaps in response to the ample research documenting the National Geographic Society's sensational tradition of representing Others in its magazine and, more recently, television channel. See for example: C. Lutz and J. Collins, Reading National Geographic (Chicago: University of Chicago Press, 1993); Tamar Y. Rothenberg, 'Voyeurs of Imperialism: The National Geographic Magazine before World War II', in A. Godlewska and N. Smith (eds), Geography and Empire (Cambridge, MA: Blackwell, 1994), pp. 155-72.

31 Taylor Segrest, 'Festival Focus: National Geographic All Roads Film Festival', Documentary Magazine, January 2007, <http://www.documentary.org/magazine/festival-focus-nationalgeographic-all-roads-film-festival> (13 May 2011).

32 Dennis Grunes, 'Dulce Convivencia', <http://grunes.wordpress.com/2009/04/21/dulce-convivencia-filoteo-gomez-martinez-2004/> (13 May 2011).

33 The Mixe are one of the 16 ethnolinguistic groups living in the state of Oaxaca. The 2010 Mexican Census counted 132,759 Mixe speakers over the age of five. An official, online profile of San Miguel Quetzaltepec can be reviewed at: <http://www.e-local.gob.mx/work/ templates/enciclo/oaxaca/municipios/20275a.htm>. According to this source, a 2005 national census determined there were 6015 people living in this municipio, 5428 of them speak an indigenous language, and $96 \%$ of those employed dedicate themselves to activities in the primary sector of the economy. The 2010 Census counted 7293 people living in this municipio. Until the recent arrival of satellite-mediated programming, a high school education was not available in the community where Filo grew up.

34 The Centro Cultural Zapoteca Uken ke Uken was established in 2002 with the support of the Fundación Alfredo Harp Helú, a foundation funded by the Mexican billionaire of the same name, who made a fortune selling Banamex to Citigroup in 2001. A recent description of its activities is found at: <http://huboaxaca.wordpress.com/noticias/\#yalalag> (15 May 2011). For a far less rosy vision of how the cultural politics of this center informs a tense geopolitical situation, see Todd A. Eisenstadt, Politics, Identity, and Mexico's Indigenous Rights Movements (New York: Cambridge University Press, 2011), pp. 150-2.

35 See the essays written by Juan José Rendón Monzón, Jaime Martínez Luna, and others in La comunalidad: moda de vida en los pueblos indios (Mexico City: CONACULTA, Direccíon General de Culturas Populares e Indígenas, 2003), as well as Jaime Martínez Luna, Comunalidad y desarrollo (Mexico City: CONACULTA, Direccíon General de Culturas Populares e Indígenas, and Centro de Apoyo al Movimiento Popular Oaxaqueño, A.C., 2003).

36 For Esteva's description of the Unitierra, see Gustavo Esteva, 'Reclaiming Our Freedom to Learn', Yes!, Winter, 2008, <http://www.yesmagazine.org/issues/liberate-your-space/ reclaiming-our-freedom-to-learn $>$ (15 May 2011). For a more detailed discussion of the cultural activism co-produced by Esteva and his associates, see Smith, 'Locating Post-Colonial 
Technoscience'. And you'll find an excellent example of the sort of transnational dialogue that sparked these sorts of theoretical collaboration in L. Meyer and B. Maldonado Alvarado (eds), New World of Indigenous Resistance: Noam Chomsky and Voices from North, South, and Central America (San Francisco, CA: City Lights Books and Open Media Series, 2010), which includes essays by Esteva, Jaime Martínez Luna, and many others. Several essays discuss the concept and practices of comunalidad.

37 Ivan Illich (1926-2002) wrote critiques of professionalized education and medical practice that had enormous impact throughout the world. Indeed, there's a journal devoted to 'the thought and writing of Ivan Illich and his circle', see <http://ivan-illich.org/journal/index. php/IJIS> (13 May 2011).

38 One example of such activities is Filo's participation in the Taller de Entrenamiento en Video Indigena y Comunitario in February-March 2005. This three week workshop devoted to the art and science of scriptwriting was held at Cuba's Escuela Internacional de Cine y Televisión, coordinated by the Consejo Latinoamericano de Cine y Video de Pueblos Indígenas (CLACPI), and financed by UNESCO's Oficina Regional de Cultura para América Latina y el Caribe in La Habana. Additionally, Filo helped Ojo de Agua produce a couple of the almost 30 videos it made for a television series called Pueblos de México that the NGO made for Mexico's Secretaría de Educación Pública and the Instituto Latinoamericano de la Comunicación Educativa.

39 Dulce Convivencia also won the Audience Award for Best Documentary at La Matatena, the Eleventh International Film Festival for the Young and the Not So Young in Mexico City (August 2006).

40 For studies of how the Mexican state operates in the shadows, see: John Gledhill, Power and its Disguises: Anthropological Perspectives on Politics (London: Pluto Press, 2000); Kristin Norget, 'Caught in the Cross-Fire: Militarization, Paramilitarization and State Violence in Oaxaca, Mexico', in C. Menjívar and N. Rodríguez (eds), When States Kill: Latin America, the U.S., and Technologies of Terror (Austin: University of Texas Press, 2005), pp. 115-42; Monique Nuijten, Power, Community and the State: The Political Anthropology of Organisation in Mexico (London: Pluto Press, 2003).

41 This event, held in November at the Universidad Veracruzana in Xalapa, was the Tercer Encuentro Internacional de Cine y Video Etnográfico 2005, Antropología De Las Diferencias: Miradas multidisciplinarias desde el cine, video y otras tecnologías de comunicación [Third International Symposium on Ethnographic Film and Video 2005, Anthropology of Differences: Multidisciplinary Gazes from Film, Video, and Other Communication Technologies]. The year before Filo had participated in the Encuentro de Nuevas Fronteras y Horizontes del Cine Etnográfico [Symposium on the New Borders and Horizons of Ethnographic Video]. Scholars working with the national Center for Investigation and Higher Studies in Social Anthropology (CIESAS) orchestrated both events to bring researchers who are interested in the culturalpolitical and theoretical potential of video together with video makers who are dedicated to the coordination and production of videos that envision alternative perspectives.

42 Josefina Fernández, Cuerpos desobedientes: travestismo e identidad de género (Buenos Aires: Edhasa, 2004).

43 The Partido Revolucionario Institucional (PRI - Institutional Revolutionary Party) first took form in the late 1920s and continues to dominate Mexican politics, although the first election of a President not affiliated with the PRI in 2000 is often taken as a sign of its diminishing influence. For an overview of the hybrid election practices that have become more visible in Oaxaca since its state constitution was revised to legally recognize traditional practices of communal governance, see D. Recondo, 'From Acclamation to Secret Ballot: The 
Hybridization of Voting Procedures in Mexican-Indian Communities', in R. Bertrand, J. Briquet and P. Pels (eds), The Hidden History of the Secret Ballot (Bloomington: Indiana University Press, 2007), pp. 156-79.

44 These practices are commonly collected beneath the rubric of usos y costumbres, and they include the appointment of men to cargo positions on committees that oversee community governance during open community assemblies and tequio, the obligatory contribution to community labor projects. See G.C. Ángeles Carreño and J. Hernández Díaz (eds), Ciudadanías diferenciadas en un estado multicultural: los usos y costumbres en Oaxaca (México, DF: Siglo XXI Editores, 2007); Todd Eisenstadt, 'Usos y costumbres and postelectroal conflicts in Oaxaca, Mexico, 1994-2004. An empirical and normative assessment', Latin American Research Review, 42, 2007, pp. 52-77; María Cristina Velásquez, El nombramiento: las elecciones por uso y costumbres en Oaxaca (Oaxaca, México: Instituto Estatal Electoral, 2000).

45 Valuable for understanding these events in Quetzaltepec and the recent history that led to them is the work of Lourdes Morales Canales: 'La ingobernabilidad en San Miguel Quetzaltepec: la revuelta mixe de Chuxnabán’, En Marcha: Realidad Municipal de Oaxaca, 50, 2003, pp. 7-9; 'Conflicto electoral y cambio social: el caso de San Miguel Quetzaltepec, Mixes', in G.C. Ángeles Carreño and J. Hernández Díaz (eds), Ciudadanías diferenciadas, pp. 151-74. Additionally, an outside observer's report of the municipal election in Quetzaltepec can be found at <http://www.usosycostumbres.org/estudios.htm> (15 May 2011) and linked to this report is a page featuring a useful collection of news resources regarding related events: <http://www.usosycostumbres.org/quetzaltepec.htm> (15 May 2011). Incidentally, the Usos y Costumbres website was created, by a member of Ojo de Agua, for EDUCA Servicios para una Educación Alternativa A.C., a Oaxaca-based NGO dedicated to civic education, with a particular emphasis on elections and fair governance. For information, see <http://www.educaoaxaca.org > (15 May 2011).

46 Further evidence of the irregularities surrounding Gregorio's election and continued support by the PRI is the absence of his name in the list of Municipal Presidents included in the community's entry in the online Encyclopedia of Mexico's Municipios that is noted above in note 33.

47 See Note 44 and Jonathon Fox and Josefina Aranda, Decentralization and Rural Development in Mexico: Community Participation in Oaxaca's Municipal Funds Program (La Jolla, University of California-San Diego, Center for U.S.-Mexican Studies, 1996).

48 For example, see: James Dow and Alan Sandstrom (eds), Holy Saints and Fiery Preachers: The Anthropology of Protestantism in Mexico and Central America (Westport, CT: Praeger, 2001); Carolyn Gallaher, 'The Role of Protestant Missionaries in Mexico's Indigenous Awakening', Bulletin of Latin American Research, 26, 2007, pp. 88-111; Toomas Gross, 'Farewell to Fiestas and Saints? Changing Catholic Practices in Contemporary Rural Oaxaca', Journal of Ethnology and Folkloristics, 3, 2009, pp. 3-19.

49 In Mexico, the word pueblo doesn't only mean a particular village, but also a people.

50 But see Amalia Córdova, 'The Money Problem', Cultural Survival Quarterly: Indigenous Peoples Bridging the Digital Divide summer, 2005, pp. 18-21.

\section{Biographical note}

Laurel C Smith is Assistant Professor of Geography and Environmental Sustainability at the University of Oklahoma. Her research focuses on the cultural geographies of technoscience in the Americas. With ethnographic and historical inquiry, she asks after the geopolitics of knowledge production that shape visualizations of indigeneity. 